\title{
Nutritional status of children in slums of Dhaka, Bangladesh
}

\author{
Mohammad Habibur Rahman* \\ Department of Organic Agricultural Sciences, Kassel University, Hesse, Germany
}

\begin{abstract}
The nutritional status of children in slums of Dhaka is a sensitive indicator of health, economy and the sustainable development of Bangladesh. The research highlights the consequence of anthropometric measurements and nutritional status related other issues are taken of 102 children. The survey with a structured questionnaire was conducted by the researcher during $15^{\text {th }}$ April 2015 to $6^{\text {th }}$ June, 2015 among 102 children aged between 2 to 12 years from Mirpur, Kuril and Kamalapur slums $(\mathrm{N}=102)$ in Dhaka city. To determine hypothesis statistical data analysis QtiPlot and MS Excel software tools were used and hypothesis were tested. Bi-variant and analyses were used to determine the nutritional status of children and identify the relationship of common factors with the nutritional status of children. The research presents a number of results, $33.5 \%$ of the children age between 2 to 12 years are suffering from malnutrition. According to the BMI results, $32 \%$ of the children have undernourished problem. The socio-economical status of the children are pitiable. The children families mean monthly household incomes are affecting their health and nutritional status. The study reveals that $76.4 \%$ of the children are suffering from diseases for last one month because of their sanitation and hygiene status. The research also highlights the nutritional status of the children influenced by their parents awareness, socio-economical and demographic condition, nutrient intake, breastfeeding practice, good hygiene practice, sanitation system. Malnutrition along with high morbidity rates, this action may occur the children from their future unexpected problem during motherhood and hamper cognitive development. Nutritional education programs need to be implemented to improve the nutritional status. The present study generates information which indicates that the nutritional status of the children should not be overlooked and suitable approaches designed to improve their nutrition should be considered and studies elaborately in the future.
\end{abstract}

\section{Introduction}

Bangladesh is the ninth most populous countries in the world [1] 1,203 persons per sq. km are living in Bangladesh [2] and Dhaka the capital of Bangladesh, one of the most densely populated cities in the world [3]. The population in slums of Dhaka city is increasing at an alarming rate due to migration by the rural poor. Slums are the spatial symptoms of urban poverty, social exclusion, and improper government policies [4]. Almost $28 \%$ people of Dhaka city are living in the slums under very miserable condition [5] and most of them are undernourished, illiterate and do not have knowledge about the nutritional value of foods [6]. Due to poor sanitation and congested living with 4 to 5 people, they often suffering from diseases like diarrhea, dysentery, typhoid, dengue and pneumonia [7]. Specially, children who are naturally innocent, vulnerable, and dependent often suffering from malnutrition [8]. The nutritional status of these children is a alert sign of the country's health, sustainable nutrition and economy. Malnutrition of children is a serious problem in slums of Dhaka [9]. Malnutrition is one kind of situation in which long-lasting lack of one or more nutrients retards physical development or causes specific clinical disorders, e.g. low birth weight, wasting, stunting, underweight, vitamin A deficiency, iodine deficiency disorder, iron deficiency anemia, etc. [10]. Bangladesh is one of the countries with the highest rate of children malnutrition [2] and up to $40 \%$ of children under the age of 5 years are suffering from chronic malnutrition [11] and malnutrition rate of children in slums is even worse [12]. Protein-energy malnutrition, iron deficiency anemia, iodine deficiency disorders, and vitamin A deficiency are common for children in the slums of Dhaka city [13] and the main reasons for that their poor social, economic and demographic conditions, including family income, assets, morbidity, employment, total household expenditure, mother's education, social networks, hygiene and sanitation and consumption knowledge [6,7]. One of the ICDDR,B's Centre for Nutrition and Food Security baseline survey in Bangladesh showed that undernutrition is high among young children, $41 \%$ of children were found stunted, $33 \%$ underweight and $11 \%$ wasting [14] .

\section{Research aim and objectives}

The research carried out to assess the nutritional status of under the age of 2 to 12 years children in slums of Dhaka city.

The associated major objectives include: 1) To find out the nutritional status of the children through anthropometric measurements and dietary assessment. 2) To find out the demographics and socioeconomical characteristic of the study children. 3) To determine the health, and sanitation condition of the children.

\section{Materials and methods}

\section{Research site}

In this research, Mirpur slum of Mirpur Thana, Kamalapur slum of

Correspondence to: Mohammad Habibur Rahman, Department of Organic Agricultural Sciences, Kassel University, Hesse, Germany, E-mail: tuki.st07@gmail.com

Key words: slums, malnutrition, nutritional status, food intake, hygiene and sanitation introduction

Received: September 03, 2015; Accepted: September 22, 2015; Published: September 25, 2015 
Motijheel Thana and Kuril slum of Badda Thana in Dhaka district have been chosen for the survey.

\section{Research design}

A survey was carried out among 102 children of Dhaka slums age between 2 to 12 years during April to June, 2015 with format permission from the local authority and by taking informal consent. It was a cross-sectional survey and divided into three clusters (Mirpur, Kuril and Kamalapur slums) in Dhaka city. Dietary data, socioeconomic, demographic, disease variables and anthropometric data - height, weight and BMI was collected by using a structural questionnaire and nutritional status assessed. The research has been conducted in two steps.

Firstly, the necessary data has been extracted from anthropometric cross-sectional health survey and each children gave a sample of food frequency.

Secondly, the extracted data has been assessed and compared with certain standards by analyzing specific contents.

\section{Data collection}

Data collection is the process of gathering information. The data collection process of this study was a primary research (field research). Total 102 children (respondents) have been selected of three different slums in Dhaka city and samples had been taken from these three clusters (slums) by using the questionnaire and made the interviews. Random sampling technique was used for data collection. Random Sampling is a probability sampling method, starting point is determined randomly and from then on the systematically each nth element is drawn [15]. The children's own mother language Bengali had been used during data collection.

\section{Data analysis}

For data analysis an important first step is summarize and display of the data [16]. In the current research, data were edited. Editing involves carefully checking survey data for completeness, legibility, consistency, and accuracy. The collected data were evaluated, categorized, grouped and interpreted aiming at the objectives of the study. Then, the relevant data processed and analyzed by using statistical software QtiPlot and Microsoft excel. In quantitative research, tables and graphs are used to display data and convey meaning in the analysis [17].

\section{Results}

Table 1 illustrates a total 102 children have studied. Of the participants $32.35 \%$ are aged 6 to 9 years, $48.04 \%$ are aged between 2 to 5 years and the remaining $19.61 \%$ are between 10 to 12 years old. Table 2 shows that total $31.8 \%$ children BMI are underweight $(<14.5)$. On the other hand, $66.7 \%$ children's BMI normal (14.5-21.5) and $2 \%$ are overweight.

Figure 1 shows that $62 \%$ of the children's family household income 8,000 to $12,000+$ BDT (Bangladeshi Taka), $6 \%$ of the children's

Table 1. Distribution of the children's by their age group $(\mathrm{N}=102)$.

\begin{tabular}{|c|c|c|}
\hline Age (year) & Frequency (N) & Percent (\%) \\
\hline $2-5$ & 49 & 48.04 \\
\hline $6-9$ & 33 & 32.35 \\
\hline $10-12$ & 20 & 19.61 \\
\hline Total & 102 & 100 \\
\hline
\end{tabular}

Source: (author's own construction and calculation according to own data source)
Table 2. Distribution of the children's by age group with related to Body Mass Index (BMI) (aged 2 to 12 years) $(\mathrm{N}=102)$.

\begin{tabular}{|c|c|c|c|c|}
\hline $\begin{array}{c}\text { Age Group } \\
\text { (years) }\end{array}$ & \multirow{2}{*}{$\mathbf{N}(\%)$} & \multicolumn{3}{|c|}{ BMI } \\
\cline { 3 - 5 } & & $\begin{array}{c}\text { Under } \\
\text { nourished } \\
(<\mathbf{1 4 . 5}) \mathbf{n}(\%)\end{array}$ & $\begin{array}{c}\text { Normal } \\
(\mathbf{1 4 . 5}-\mathbf{2 1 . 5}) \mathbf{n}(\%)\end{array}$ & $\begin{array}{c}\text { Overweight } \\
(\mathbf{2 1 . 5}) \mathbf{n}(\%)\end{array}$ \\
\hline $2-5$ & $49(48.039)$ & $18(36.72)$ & $29(59.20)$ & $02(4.08)$ \\
\hline $6-9$ & $33(32.352)$ & $09(27.27)$ & $24(72.73)$ & $00(00)$ \\
\hline $10-12$ & $20(19.607)$ & $05(25.00)$ & $15(75.00)$ & $00(00)$ \\
\hline Total 102(\%) & $32(31.8 \%)$ & $68(66.7 \%)$ & $02(1.97 \%)$ \\
\hline
\end{tabular}

Source: (author's own construction and calculation according to own data source with compare to WHO children's BMI charts)

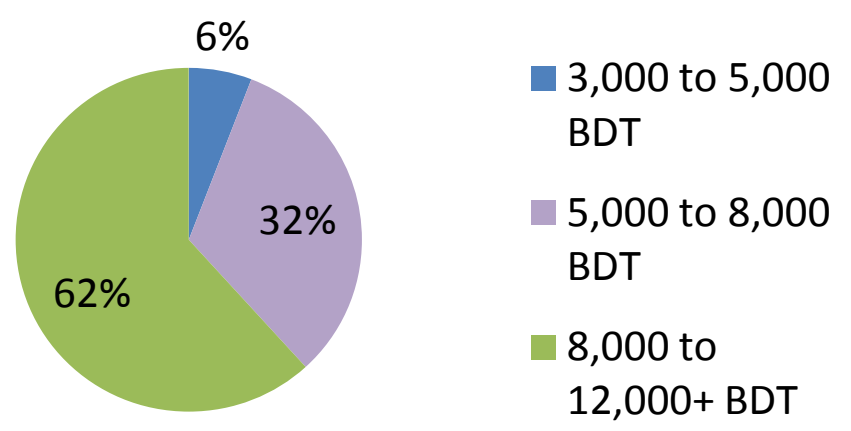

Source: (author's own construction and calculation according to own data source) Figure 1: Distribution of the children's by monthly household income $(\mathrm{N}=102)$.

Table 3. Distribution of the children's by monthly household income with related to nutritional status/BMI $(\mathrm{N}=102)$.

\begin{tabular}{|c|c|c|c|}
\hline $\begin{array}{c}\text { Per capita } \\
\text { income (BDT) }\end{array}$ & $\mathbf{N}(\%)$ & n (\%) & BMI \\
\hline \multirow[b]{3}{*}{$3,000-5,000$} & \multirow[b]{3}{*}{$6(\%)$} & $05(83.33)$ & Under nourished $(<14.5)$ \\
\hline & & $01(16.67)$ & Normal ( 14.5-21.5) \\
\hline & & $00(00)$ & Overweight $\left(21.5^{+}\right)$ \\
\hline \multirow[b]{3}{*}{$5000-8,000$} & \multirow{3}{*}{$33(32 \%)$} & $13(39.4)$ & Under nourished $(<14.5)$ \\
\hline & & $20(60.6)$ & Normal ( $14.5-21.5)$ \\
\hline & & $00(00)$ & Overweight $\left(21.5^{+}\right)$ \\
\hline \multirow[b]{3}{*}{$8,000-12,000$} & \multirow{3}{*}{$63(62 \%)$} & $14(22.2)$ & Under nourished $(<14.5)$ \\
\hline & & $47(74.6)$ & Normal ( $14.5-21.5)$ \\
\hline & & $02(3.2)$ & Overweight $\left(21.5^{+}\right)$ \\
\hline Total & $102(100)$ & 102 & BMI (14.5 to $21.5+)$ \\
\hline
\end{tabular}

Source: (author's own construction and calculation according to the own data source)

household income is 3,000 to $5,000 \mathrm{BDT}$ and $32 \%$ is 5,000 to 8,000 BDT. But the incomes of these three groups are not enough for their living, accommodation, foods and others.

Table 3 shows that $6 \%$ of the children monthly household incomes are between Tk 3,000-5,000 and undernourished $(<14.5)$ 83\%. On the other hand, $32 \%$ of the children monthly household incomes are between Tk 5,000-8,000 and undernourished almost $40 \%$ and $62 \%$ of the children monthly household incomes are between Tk 8,000-12,000 and undernourished almost $22 \%$.

Table 4 shows that the relationship amongst the nutrient intake and per capita income of the children. The children are divided into three groups based upon the household per capita income. Children 
Table 4. Relationship between per capita income and nutrient intake $(\mathrm{N}=102)$.

\begin{tabular}{|c|c|c|c|c|}
\hline $\begin{array}{c}\text { Per capita } \\
\text { income }\end{array}$ & No. of children & $\begin{array}{c}\text { Mean calorie } \\
\text { intake (kcal) }\end{array}$ & $\begin{array}{c}\text { Mean protein } \\
\text { intake (g) }\end{array}$ & $\begin{array}{c}\text { Mean iron } \\
\text { intake (mg) }\end{array}$ \\
\hline $3,000-5,000$ & 06 & 986.66 & 13.92 & 5.002 \\
\hline $5,000-8,000$ & 33 & 1029.75 & 16.87 & 6.106 \\
\hline $8,000-12,000$ & 63 & 1102.48 & 18.84 & 6.018 \\
\hline Total & 102 & 1039.40 & 16.55 & 5.70 \\
\hline
\end{tabular}

Source: (author's own construction; the data was calculated on the basis of WHO/FAO technical committee dietary guidelines for children's data)

Table 5. Anthropometric characteristic of the children ( $\mathrm{N}=102)$ (aged 2 to 12 years).

\begin{tabular}{|l|c|c|c|c|}
\hline & Minimum & Maximum & Mean & St. D. \\
\hline Height $(\mathrm{cm})$ & 81.28 & 147.32 & 109.72 & \pm 5.6 \\
\hline Weight $(\mathrm{kg})$ & 11.0 & 30.0 & 15.83 & \pm 9.4 \\
\hline BMI $\left(\mathrm{kg} / \mathrm{m}^{2}\right)$ & 11.44 & 18.16 & 15.74 & \pm 3.5 \\
\hline
\end{tabular}

Source: (author's own construction; own primary data source)

Table 6. Mean per capita food intake per day $(\mathrm{N}=102)$.

\begin{tabular}{|c|c|c|}
\hline Food sources & Mean food intake (g/d) & Percentage (\%) \\
\hline Cereals & 131.31 & 45.19 \\
\hline Pulses & 14.91 & 5.13 \\
\hline Green Leafy Vegetables & 22.10 & 7.61 \\
\hline Non Leafy Vegetables & 24.26 & 8.35 \\
\hline Fruits & 12.45 & 4.29 \\
\hline Meat, fish and egg & 60.68 & 20.88 \\
\hline Milk and milk products & 24.87 & 8.55 \\
\hline Total & 290.58 & 100 \\
\hline
\end{tabular}

Source: (author's own construction and calculation; according to own data)

Table 7. Mean per capita nutrient intake by food sources $(\mathrm{N}=102)$.

\begin{tabular}{|c|c|}
\hline Nutrients & Mean per capita intake \\
\hline Cal. intake $(\mathrm{kcal})$ & 1039.40 \\
\hline Protein $(\mathrm{g})$ & 16.55 \\
\hline Fat from foods $(\mathrm{g})$ & 14.11 \\
\hline Carbohydrate $(\mathrm{g})$ & 139.53 \\
\hline Vitamin C (mg) & 22.72 \\
\hline Iron $(\mathrm{mg})$ & 5.70 \\
\hline Calcium $(\mathrm{mg})$ & 407.75 \\
\hline
\end{tabular}

Source: (author's own construction; data calculation on the basis of FAO-Infants, children, and adolescents energy, protein and micronutrients requirement data)

from lower income families calorie, protein and iron intake which are seen lower than the children from higher income families. Mean energy, protein and iron intake are highest $1102.4859 \mathrm{kcal}, 16.55 \mathrm{~g}, 5.70$ mg respectively, for the children who are from families of highest per capita income between Tk. 8,000-12,000/month.

Table 5 illustrates that the mean height of the children $(\mathrm{cm})$ are $109.72 \pm 5.6$, weight $(\mathrm{kg})$ was $15.83 \pm 9.4$ and Mean Body Mass Index (BMI) $\left(\mathrm{kg} / \mathrm{m}^{2}\right)$ are $15.74 \pm 3.5$. Mean BMI is 15.74 which is acceptable but not enough because $32 \%$ children are under nourished.

Table 6 shows that total children mean food intake 290.58 gm per day. The contribution from cereals are $131.31 \mathrm{gm}$ which is $45.19 \%$ of total food intake per day almost half of the total food intake. Food consumption from animal sources such as meat, fish and egg are 60.68 gm which is $20.88 \%$ of total food intake and animal dairy \& dairy products are $24.87 \mathrm{~g}$ per day which is $8.55 \%$ of total food intake per day per children and others food intake respectively.

Table 7 shows that the mean calorie intake are $1039.40 \mathrm{kcal}$, protein intake are $16.55 \mathrm{~g} / \mathrm{d}$. The mean $\mathrm{CHO}$, fat, vit-C, iron and calcium intake are found $139.53 \mathrm{~g}, 14.11 \mathrm{~g}, 22.72 \mathrm{mg}, 5.70 \mathrm{mg}$ and $407.75 \mathrm{mg}$ respectively/day.

Table 8 illustrates that the mean daily energy requirement on the basis of their age group of the studied children are $1316.66 \mathrm{kcal}$ and most mean energy balance deference is $-387.52 \mathrm{kcal}$ of the age group 10 to 12 years of children but age group 2 to 5 years old children mean energy balance deference looking -191.74.

Table 9 shows that per capita energy and nutrient intake and mean percentage fulfillment of the requirement. The table shows gross inadequacy in terms of $\%$ fulfillment of the recommended allowance for energy, protein, iron, fat, $\mathrm{CHO}$, vitamin- $\mathrm{C}$ and calcium and different age group of children with different amount of nutrients requirement and intake. The percentage of nutrients fulfillment/day is lower than RDA and it came from seven individual nutrients of foods e.g. energy (kcal) $76 \%$, protein $68 \%$, fat $52 \%$, iron $69 \%$, calcium $43 \%$ and $\mathrm{CHO}$ $76 \%$ mean fulfillment per day. Vitamin-C intake is $82 \%$ and higher percentage than others nutrient groups.

Table 10 shows that the relation between BMI and nutrient intake.

Table 8. Distribution of the children's by their mean energy intake per day $(\mathrm{N}=102)$.

\begin{tabular}{|c|l|c|c|c|}
\hline $\begin{array}{c}\text { Age group } \\
\text { (years) }\end{array}$ & $\begin{array}{c}\text { No. of children } \\
\text { N (\%) }\end{array}$ & $\begin{array}{c}\text { Mean energy } \\
\text { requirement/day } \\
\text { (kcal) }\end{array}$ & $\begin{array}{c}\text { Mean energy } \\
\text { intake/day } \\
\text { (kcal) }\end{array}$ & $\begin{array}{c}\text { Mean energy } \\
\text { balance/day } \\
\text { (kcal) }\end{array}$ \\
\hline $2-5$ & $49(48.039)$ & 1150.00 & 958.26 & -191.74 \\
\hline $6-9$ & $33(32.352)$ & 1300.00 & 1047.4 & -252.55 \\
\hline $10-12$ & $20(19.607)$ & 1500.00 & 1112.4 & -387.52 \\
\hline
\end{tabular}

Source: (author's own construction; the data was calculation on the basis of WHO/FAO data)

Table 9. Per capita energy and nutrient intake and mean percentage fulfillment of the requirement $(\mathrm{N}=102)$.

\begin{tabular}{|c|c|c|c|c|c|}
\hline Nutrients & $\begin{array}{l}\text { Age group } \\
\text { (years) }\end{array}$ & Intake & Requirement & $\%$ of Fulfilment & $\begin{array}{l}\text { Mean \% of } \\
\text { Fulfilment }\end{array}$ \\
\hline \multirow{3}{*}{$\begin{array}{c}\text { Energy } \\
\text { (kcal) }\end{array}$} & $2-5$ & 958.26 & 1200 & $79 \%$ & \multirow{3}{*}{$76 \%$} \\
\hline & $6-9$ & 1047.4 & 1350 & $77 \%$ & \\
\hline & $10-12$ & 1112.4 & 1500 & $74 \%$ & \\
\hline \multirow{3}{*}{ Protein (g) } & $2-5$ & 13.43 & 19 & $70 \%$ & \multirow{3}{*}{$68 \%$} \\
\hline & $6-9$ & 17.17 & 24 & $71 \%$ & \\
\hline & $10-12$ & 19.04 & 29 & $65 \%$ & \\
\hline \multirow{3}{*}{$\begin{array}{l}\text { Fat from } \\
\text { food }(\mathrm{g})\end{array}$} & $2-5$ & 13.02 & 20 & $65 \%$ & \multirow{3}{*}{$52 \%$} \\
\hline & $6-9$ & 14.55 & 30 & $49 \%$ & \\
\hline & $10-12$ & 14.78 & 35 & $42 \%$ & \\
\hline \multirow[t]{3}{*}{ CHO (g) } & $2-5$ & 115.70 & 158.1 & $73 \%$ & \multirow{3}{*}{$76 \%$} \\
\hline & $6-9$ & 132.07 & 178.7 & $73 \%$ & \\
\hline & $10-12$ & 170.84 & 206.2 & $82 \%$ & \\
\hline \multirow[t]{3}{*}{ Vit-C (mg) } & $2-5$ & 13.55 & 15 & $90 \%$ & \multirow{3}{*}{$82 \%$} \\
\hline & $6-9$ & 21.40 & 25 & $85 \%$ & \\
\hline & $10-12$ & 33.21 & 45 & $73 \%$ & \\
\hline \multirow[t]{3}{*}{ Iron (mg) } & $2-5$ & 5.002 & 07 & $71 \%$ & \multirow{3}{*}{$69 \%$} \\
\hline & $6-9$ & 6.106 & 10 & $61 \%$ & \\
\hline & $10-12$ & 6.018 & 08 & $76 \%$ & \\
\hline \multirow{3}{*}{$\begin{array}{l}\text { Calcium } \\
(\mathrm{mg})\end{array}$} & $2-5$ & 333.50 & 700 & $48 \%$ & \multirow{3}{*}{$43 \%$} \\
\hline & $6-9$ & 415.09 & 1000 & $42 \%$ & \\
\hline & $10-12$ & 474.41 & 1200 & $40 \%$ & \\
\hline
\end{tabular}

Source: (author's own construction and calculation according to own data source with compared to WHO/FAO data) Here age group 2-5 years: $\mathrm{n}=49 ; 6-9$ years: $\mathrm{n}=33$ and $10-12$ years: $n=20$ 
Table 10. Distribution of subjects by Body Mass Index and nutrient intake (N=102).

\begin{tabular}{|c|c|c|c|c|c|}
\hline BMI & $\begin{array}{c}\text { Num. of } \\
\text { children }\end{array}$ & $\begin{array}{c}\text { Energy } \\
\text { (kcal) }\end{array}$ & $\begin{array}{c}\text { Protein } \\
\text { (gm) }\end{array}$ & $\begin{array}{c}\text { Fat } \\
\text { (gm) }\end{array}$ & $\begin{array}{c}\text { CHO } \\
\text { (gm) }\end{array}$ \\
\hline$<14.5$ & 32 & $874 \pm 325$ & $14.5 \pm 9$ & $12.5 \pm 9$ & $113 \pm 58$ \\
\hline $14.5-21.5$ & 68 & $1040 \pm 319$ & $18 \pm 10$ & $14 \pm 8.5$ & $175 \pm 46$ \\
\hline $21.5^{+}$ & 02 & $1204 \pm 41$ & $17 \pm 1$ & $16 \pm 1.5$ & $131 \pm 11$ \\
\hline
\end{tabular}

Source: (author's own construction and calculation according to own data source)

Table 11. Comparison of per capita energy and protein intake of the children's with WFP2008, WHO-2000 and icddr'b-2010.

\begin{tabular}{|c|c|c|c|c|}
\hline Nutrients & WHO-2000 & WFP-2008 & $\begin{array}{c}\text { ICDDR'B } \\
\mathbf{2 0 1 0}\end{array}$ & Current study \\
\hline Energy(kcal) & 1020 & 1007 & 1100 & 1039.4 \\
\hline Protein(g) & 26 & 22 & 19.5 & 16.60 \\
\hline
\end{tabular}

Source: (author's own construction; comparison with WHO, WFP, ICDDR'B and curren study's data)

78

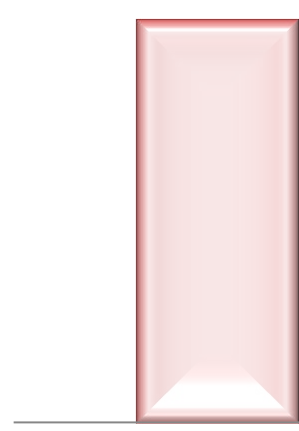

Yes
24

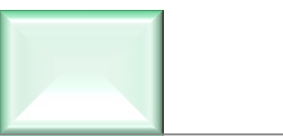

No
Source: (author's own construction and calculation according to own data source

Figure 2: Distribution of morbidity pattern among the children of last one month $(\mathrm{N}=102)$.

68 children has normal BMI and they consumed $1040 \pm 319 \mathrm{kcal}$ energy, $18 \pm 10 \mathrm{~g}$ protein, $14 \pm 8.5 \mathrm{~g}$ fat and $175 \pm 46 \mathrm{~g}$ CHO. On the other hand, 32 children are undernourished and their BMI are below 14.5. They consumed $874 \pm 325 \mathrm{kcal}$ energy, $14.5 \pm 9 \mathrm{~g}$ protein, $12.5 \pm 9$ $\mathrm{g}$ fat and $113 \pm 58 \mathrm{~g} \mathrm{CHO}$.

Table 11 reveals that current energy intake reduced by 60.60 $\mathrm{kcal}$ as compared with icddr'b-2010 national survey. But compared to the WHO-2000 and WFP-2008 survey with the current research, the energy intake is slightly increased. The energy intake ratio of the children is fluctuated but not big margin the table shown. On the other hand, the current study shows that protein intake decreased gradually and it is $16.6 \mathrm{~g} /$ day but 15 years before it was $26 \mathrm{~g} /$ day.

Figure 3 Indicates that $31 \%$ children suffering from fever, $20 \%$ diarrhea, $23 \%$ cold \& cough and these diseases are a common issues for children in slums. The figure also shows that $7 \%, 12 \%$ and $7 \%$ of the children suffering from pneumonia, skin disease and jaundice respectively.

Table 12 indicates that there is a relationship between the morbidity patterns (last one month) of the children related with BMI.
91\% of undernourished children suffering from any sort of diseases. On the other hand, the study found that, $72 \%$ of the normal children are also suffering from any sort of diseases. The underweight children morbidity rate is higher than the others BMI group children though. But there is no big margin between BMI and the morbidity pattern of the children.

Table 13 reveals that the types of water children's and their family used for drinking and for household tasks. Here children's family, $\mathrm{N}=54$; Total children's 102 , so $102 / 54=1.88$ this value are average

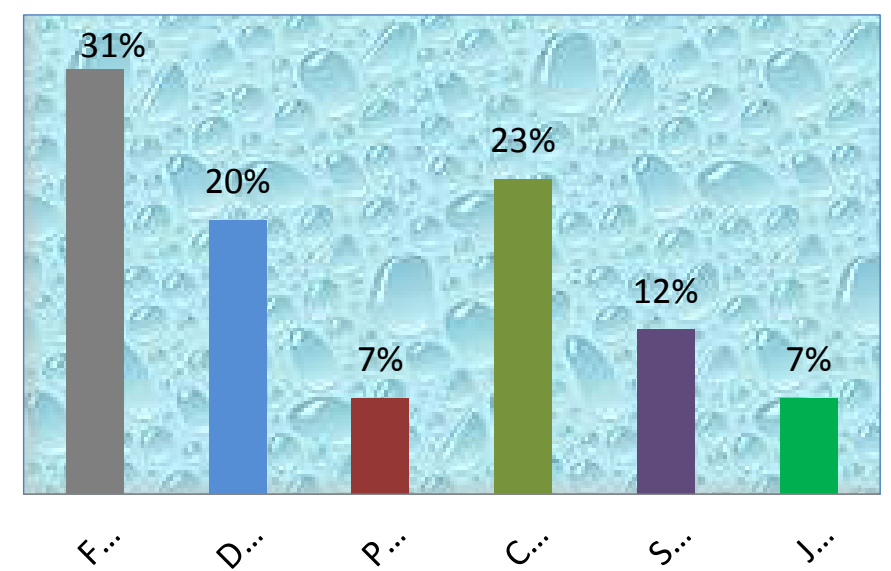

Source: (author's own construction and calculation according to own data source)

Figure 3: Distribution of the children's by disease $(\mathrm{N}=78)$ (according to figure 1).

Table 12. Relation between the morbidity patterns (last one month) of the children's related with BMI $(\mathrm{N}=102)$.

\begin{tabular}{|c|c|c|c|c|}
\hline BMI & $\begin{array}{c}\text { No. of } \\
\text { children's (N) }\end{array}$ & $\begin{array}{c}\text { Suffered } \\
\text { from disease }\end{array}$ & $\begin{array}{c}\text { Not suffered from } \\
\text { disease }\end{array}$ & $\begin{array}{c}\text { \% suffered } \\
\text { from disease }\end{array}$ \\
\hline Undernourished & 32 & 29 & 03 & 91 \\
\hline Normal & 68 & 49 & 19 & 72 \\
\hline Overweight & 02 & 00 & 02 & 00 \\
\hline Total & 102 & 78 & 24 & 76 \\
\hline
\end{tabular}

Source: (author's own construction and calculation according to own data source)

Table 13. Distribution of the source of water using the children's family per day (total children's family 54 and number of children's 102) $(\mathrm{N}=54)$.

\begin{tabular}{|c|c|c|c|}
\hline \multicolumn{2}{|c|}{ Sources of water } & $\begin{array}{c}\text { No. of children's } \\
\text { family (N=54) }\end{array}$ & Percentages (\%) \\
\hline \multirow{4}{*}{ For drinking } & Supply water & 22 & 41 \\
\cline { 2 - 4 } & Tube well water & 15 & 28 \\
\cline { 2 - 4 } & Cannel/river water & 00 & 00 \\
\cline { 2 - 4 } & $\begin{array}{c}\text { Supply and Tube well } \\
\text { water both }\end{array}$ & 17 & 31 \\
\hline \multirow{3}{*}{$\begin{array}{c}\text { For household } \\
\text { works }\end{array}$} & Supply water & 16 & 30 \\
\cline { 2 - 4 } & Tube well water & 12 & 22 \\
\cline { 2 - 4 } & Cannel/river water & 06 & 11 \\
\cline { 2 - 4 } & $\begin{array}{c}\text { Supply and Tube well } \\
\text { water both }\end{array}$ & 20 & 37 \\
\hline
\end{tabular}

Source: (author's own construction and calculation according to own data source) Here children's family, $\mathrm{N}=54$; Total children 102 , so $102 / 54=1.88$ this values are average children's per house. 
children per house. Highest $41 \%$ family are using supply water for drinking and another major source is tube well water which are $28 \%$ but $31 \%$ family used supply \& tube well water both for drinking. On the other hand, $30 \%$ family are using supply water for household works and $22 \%$ family are using tube well water. $37 \%$ family are using supply \& tube well water both for household tasks. But one of the concerning issues is that $11 \%$ of family are using cannel/river water which is so much dirty and it is not permitted for using.

Table 14 shows that the types of human and household waste disposal of the children. 50\% family are disposing their human waste near outside the house, $35 \%$ of the children with family disposing human waste far away outside the house and $15 \%$ of the children and their family disposing human waste near outside the house \& far away outside the house both. On the other hand, 59\% of the family are disposing their household waste near outside the house, $26 \%$ are disposing household waste far away outside the house and 13\% are disposing household waste near outside the house \& far away outside the house both. Only $2 \%$ of the children's family found they put household waste inside the house.

Figure 4 illustrates that the types of latrine children using for human waste disposal. Here the figure shows that $59 \%$ of the children are using non-sanitary latrine and $33 \%$ are using sanitary latrine. On the other hand, $8 \%$ children use sewer (open drain).

Table 14. Distribution of the human waste and household waste disposal status of the children's family (total children's family 54 and number of children's 102) (N=54).

\begin{tabular}{|c|c|c|c|}
\hline \multicolumn{2}{|c|}{ Sources of water } & \multirow{2}{*}{\begin{tabular}{|c|}
$\begin{array}{c}\text { No. of children's } \\
\text { family }(\mathbf{N}=\mathbf{5 4})\end{array}$ \\
00 \\
\end{tabular}} & \multirow{2}{*}{$\begin{array}{c}\text { Percentages (\%) } \\
00\end{array}$} \\
\hline \multirow{4}{*}{$\begin{array}{c}\text { For human waste } \\
\text { disposal }\end{array}$} & Inside the house & & \\
\hline & Near outside the house & 27 & 50 \\
\hline & Far away outside the house & 19 & 35 \\
\hline & $\begin{array}{l}\text { Near outside the house and } \\
\text { far away outside the house } \\
\text { both }\end{array}$ & 08 & 15 \\
\hline \multirow{4}{*}{$\begin{array}{l}\text { For household } \\
\text { waste disposal }\end{array}$} & Inside the house & 03 & 02 \\
\hline & Near outside the house & 32 & 59 \\
\hline & Far away outside the house & 14 & 26 \\
\hline & $\begin{array}{l}\text { Near outside the house and } \\
\text { far away outside the house } \\
\text { both }\end{array}$ & 07 & 13 \\
\hline
\end{tabular}

Source: (author's own construction and calculation according to own data source)
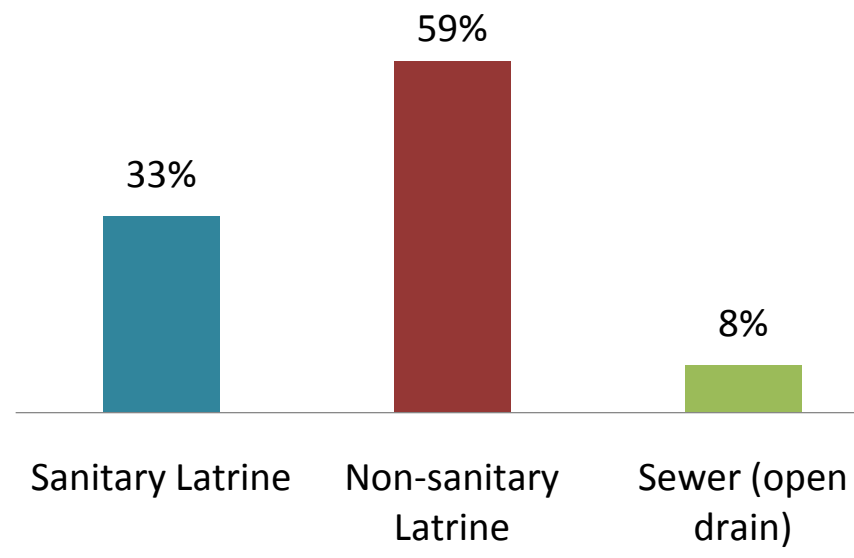

Source: (author's own construction and calculation according to own data source)

Figure 4: Distribution of the types of latrine children's have used for human waste disposal $(\mathrm{N}=102)$.
Table 15 indicates that the relation of the health issues like morbidity pattern with using water, human waste disposal and household waste disposal status of the children. $75 \%$ of the children are suffering from disease and it is related with the types of drinking water. On the other hand, $79 \%$ of the children are suffering from disease with related to household used water. Similarly, $75 \%$ and $80 \%$ children's disease also related with human waste disposal and household waste disposal respectively.

\section{Discussion}

The nutritional status of the slums children is a sensitive indicator of the country's health, sustainable nutrition and economy. This present study reveals that children aged between 2-5 years are found $48 \%$ (Table 1), almost half of the total study children which is very sensitive age group of the children's whole life. Because, 2-5 years of children are suffering from malnutrition more (36.72\%) than the other two groups of children in slums of Dhaka (Table 2). According to the WFP-2009, malnourished children are birth to 5 years old at high risk of morbidity and mortality rate. Current research reveals that cereal food groups, especially rice has eaten daily (20-21 times/week) by $96.07 \%$ of the children. Therefore, malnutrition is a serious problem of children in slums of Dhaka [9]. According to the Child Nutrition Survey of Bangladesh 1990- 2005, during 1990 to 2005, the prevalence of underweight was reduced by 25.2 percentage points which was from $70.9 \%$ to $45.7 \%$ and stunting by 29.1 percentage points from $68.3 \%$ to $39.2 \%$. It was a significant reduction and the survey expected that Bangladesh achieves the target of reducing underweight prevalence to $32.9 \%$ in 2015 . Another survey conducted by Bangladesh Bureau of Statistics (BBS) [18] and according the BBS survey and WHO 2005 growth reference standards, almost $33 \%$ of children aged in between birth to 6 years were undernourished in Bangladesh. The World Health Organization illustrated that the undernourished rate was "very high", and the prevalence of wasting point out a "critical problem" in Bangladesh [19]. In Dhaka division the nutritional status of children had the lowest prevalence of wasting which was $9.7 \%$ but when it made ratio with slums children it was more than 9.7\% [19]. The current study indicates that the mean Body Mass Index (BMI) $(\mathrm{kg} / \mathrm{m} 2)$ of the children are $15.74 \pm 3.5$. Mean BMI are 15.74 which is acceptable but not enough because $32 \%$ of the children's BMI are undernourished $(<14.5)$ (Table 2). The study also shows that $33.5 \%$ of the children under the age between 2 to 12 years are suffering from malnutrition because of the total percentages of nutrients fulfillment per day is lower than Recommended Dietary Allowances (RDA) set by the relevant national and international body including ICDDR'B, Bangladesh, National Nutrition Council (NNC), Bangladesh, WHO and FAO for children. This prevalence of percentage comes from seven individual essential nutrients of food such as energy $76 \%$, protein $68 \%$, fat $52 \%$, iron $69 \%$, calcium $43 \%$ and $\mathrm{CHO} 76 \%$ mean fulfillment per day (Table 9).

On the other hand, the present study illustrates that the socioeconomical status of the slums children in Dhaka are lower than other groups of the Dhaka city and the families mean monthly household income 6833.33 BDT when the whole country's per capita mean monthly income was 8869.50 BDT (1314 US Dollars/year) [20] and these poor amount of monthly income are affecting their health, sanitation and nutritional status [13]. According to the Universal Salt Iodization Survey, 2005, millions of children are suffering from one or more types of malnutrition including underweight, Vitamin A deficiencies, iodine deficiency disorders (IDD) and anemia. According to FAO nutritional country profile-Bangladesh (1999), the children were suffering from higher rate of micronutrient deficiencies including 
Table 15. Relationship between morbidity patterns and using water, human waste disposal and household waste disposal status ( $\mathrm{N}=102$ ).

\begin{tabular}{|c|c|c|c|c|c|c|}
\hline \multicolumn{2}{|c|}{ Sources } & \multirow{3}{*}{$\begin{array}{c}\text { Percentages N (\%) } \\
42(41)\end{array}$} & \multicolumn{4}{|c|}{ Morbidity patterns } \\
\hline & & & \multirow{2}{*}{$\begin{array}{c}\text { Yes (n) } \\
31\end{array}$} & \multirow{2}{*}{$\begin{array}{c}(\mathbf{n} \%) \\
73\end{array}$} & \multirow{2}{*}{$\begin{array}{c}\text { No }(n) \\
11\end{array}$} & \multirow{2}{*}{$\begin{array}{c}(\mathrm{n} \%) \\
27\end{array}$} \\
\hline \multirow{5}{*}{ For drinking water } & Supply water & & & & & \\
\hline & Tube well water & $28(28)$ & 16 & 57 & 12 & 43 \\
\hline & Cannel/river water & $00(00)$ & 00 & 00 & 00 & 00 \\
\hline & $\begin{array}{l}\text { Supply and Tube well } \\
\text { water both }\end{array}$ & $32(31)$ & 31 & 96 & 01 & 04 \\
\hline & Total & $102(100)$ & 78 & 75 & 24 & 25 \\
\hline \multirow{5}{*}{ For household works } & Supply water & $31(30)$ & 25 & 81 & 06 & 19 \\
\hline & Tube well water & $22(22)$ & 17 & 77 & 05 & 23 \\
\hline & Cannel/river water & $11(11)$ & 10 & 91 & 01 & 09 \\
\hline & $\begin{array}{l}\text { Supply and Tube well } \\
\text { water both }\end{array}$ & $38(37)$ & 26 & 68 & 12 & 32 \\
\hline & Total & $102(100)$ & 78 & 79 & 24 & 21 \\
\hline \multirow{5}{*}{$\begin{array}{l}\text { For human waste } \\
\text { disposal }\end{array}$} & Inside the house & $00(00)$ & 00 & 00 & 00 & 00 \\
\hline & Near outside the house & $51(50)$ & 43 & 84 & 08 & 16 \\
\hline & $\begin{array}{c}\text { Far away outside the } \\
\text { house }\end{array}$ & $36(35)$ & 23 & 63 & 13 & 37 \\
\hline & $\begin{array}{c}\text { Near outside the house } \\
\text { and far away outside the } \\
\text { house both }\end{array}$ & $15(15)$ & 12 & 80 & 03 & 20 \\
\hline & Total & $102(100)$ & 78 & 75 & 24 & 43 \\
\hline \multirow{5}{*}{$\begin{array}{c}\text { For household waste } \\
\text { disposal }\end{array}$} & Inside the house & $02(02)$ & 02 & 100 & 00 & 00 \\
\hline & Near outside the house & $61(59)$ & 49 & 80 & 12 & 20 \\
\hline & $\begin{array}{c}\text { Far away outside the } \\
\text { house }\end{array}$ & $26(26)$ & 17 & 65 & 09 & 35 \\
\hline & $\begin{array}{l}\text { Near outside the house } \\
\text { and far away outside the } \\
\text { house both }\end{array}$ & $13(13)$ & 10 & 76 & 03 & 24 \\
\hline & Total & $102(100)$ & 78 & 80 & 24 & 21 \\
\hline
\end{tabular}

Source: (author's own construction and calculation according to own data source)

vitamin-A, iron, iodine and zinc deficiency in Bangladesh [21]. The present study reveals that the children intake less energy than their requirement (Table 8). Overall their energy balance is negative, protein and iron intake is $16.55 \mathrm{gm}$ and $5.70 \mathrm{mg}$ daily which are too low and not fulfillment of RDA (Table 9). Table-11 shows that the protein intake of the children are gradually decreasing day by day compared to the WHO-2000 and WFP-2008 survey with the current research but the energy intake is slightly increased. The present study shows that the energy intake ratio of the children is fluctuated but not a big margin than the other study (Table 11). Protein intake is decreased because of poverty, high price of rice and other essential commodities, low purchasing power of the children's families especially in slums children's families of Bangladesh might limit the consumption of protein. Protein intake is decreased time after time and current study shows that children intake protein $16.6 \mathrm{~g} /$ day but 15 years before it was $26 \mathrm{~g} /$ day. The insufficient consumption of protein and micronutrients results in various long and short-term health problems e.g. stunting, underweight, wasting, osteoporosis and low bone-mass [22].

The report of Child Nutrition Survey 2005, published by Bangladesh Bureau of Statistics, the prevalence of underweight was reported to $39.7 \%$ whereas the present study says that it is $31.8 \%$ undernourished in Slums of Dhaka city. Malnourished children are at high risk of morbidity and mortality [23]. Morbidity such as diarrheal disease, upper respiratory infections, blindness, skin disease can significantly reduced if children uses safe water, proper sanitation and hygienic disposal of human waste (Health, Population and Nutrition Sector Development Program, 2011-16). The present study shows that $76.4 \%$ of the children are suffering from diseases of last one month including 20\%, $31 \%$ and $12 \%$ of the children are suffering from diarrhea, fever and skin diseases respectively (Figure 2 and 3 ) and these are the common issues for children in slums of Bangladesh. The present study indicates that there are a big relationship between the morbidity patterns (last one month) of the children related with BMI and $91 \%$ of undernourished children are suffering from any sort of diseases whereas $72 \%$ of the BMI normal children are suffering from any sort of diseases last one month (Table 12). The research shows that the underweight children's morbidity rate higher than the other BMI group children. But there is no significant difference found between BMI and the morbidity pattern of the children. According to the Table 15, there are a co-relationship found between morbidity patterns and using water, human waste disposal and household waste disposal status of the children. The NHDSBD survey-2011 indicated that tube wall water and supply water are the most common sources of drinking water in Bangladesh and $94.4 \%$ of household use supply or tube well water as drinking water [24] The present study illustrates that $41 \%$ children's family are using supply water for drinking and $28 \%$ of the children's family are using tube wall water and $31 \%$ family are using supply \& tube wall water both for drinking. On the other hand, $11 \%$ of the children's family are using cannel/river's water which is so much dirty and it is not permitted for using. The current study shows that almost two-third of the children are using non-sanitary latrine which is $59 \%$ whereas $33 \%$ are using sanitary latrine. But $8 \%$ children are using sewer (open drain) which is very harmful for environment as well as children's health (Figure 4). Table 15 indicates that the relationship between morbidity patterns and using water, human waste disposal and household waste disposal status of the children. According to table-15, 75\% children suffered 
from disease with related to types of drinking water. On the other hand, $79 \%$ of the children suffered from disease with related to household used water. Similarly, $75 \%$ and $80 \%$ children's disease also related with human waste disposal and household waste disposal respectively.

Overall, in this study find out that one-third of the total children are suffering from malnutrition because of their lack of nutrients intake, BMI is poor than the standard references and their pitiable socio-economical, demographical condition as well as poor sanitation and lack of hygiene practice affecting nutritional status of the slum children in Dhaka, Bangladesh.

\section{Recommendations}

The nutritional status of the slum children are more than average in Bangladesh but they lack in nutrient intake food along with physical activities and morbidity rate, this action may occur these children from their future unexpected problem during motherhood and hamper the cognitive development. Nutrition education programs need to be implemented to improve the nutritional status. The present study has generated information which indicates that the nutritional status of this group should not be overlooked and suitable approaches designed to improve their nutrition should be considered. It should studies elaborately in future. Depending on the findings, however a set of recommendation has been made for the improvement of their nutritional status.

1. Primary focus on nutrition promotion, and the central role of the school: Health promoting schools may provide an appropriate framework for enhancing nutrition among children, at least for those who are in school. School-based programs may also encourage children to remain in school, e.g. school-feeding programs. This is particularly important for children. Community-based institutions e.g. youth groups, community clinic, local NGOs can also be involved, in addition to using media.

2. Prevention and management of nutritional problems and risks: Health care providers can deal most directly, and primarily with micronutrient deficiencies, malnutrition of the children's.

3. Nutritional assessment: Nutritional assessment should be an inherent part of preventive health care services to children. This includes anthropometry could even be regularly measured in schools or if possible in house by the Government body or NGOs.

4. Provide hygiene and health related knowledge: Hygiene and health related proper knowledge should be provided and developed by the Government body or national and international NGOs. Because the study children's morbidity rate is very high and hygienic practice is too poor. One of the important thing is that their using drinking and household water should be changed.

5. Control of Diarrheal diseases: Issues regarding implementation of micronutrient malnutrition as well as diarrheal diseases control programs are only partially addressed. Higher allocation of resources need to be made to improve the outreach of health care delivery.

6. Control of micronutrient deficiencies: Iron deficiency anemia need to be controlled and prevented in children. Iron deficiency is the predominant cause of anemia, and correcting it is an investment in adult productive and reproductive lives. Multiple mineral vitamin supplementations to correct the problem could be done for little cost. Providing free or price-subsidized micronutrient fortified food during school hours would be a further step towards improving their nutritional status. Young children's are ideal targets for food-based approaches to improving micronutrient status, in particular vitamin A and iron.

7. Improve socio-economical and environmental condition: High socioeconomic and good environmental conditions are the most important factors associated with lower prevalence of malnutrition. The Government and the associated stockholders should be taken the proper steps for improving their socio-economical and environmental status.

8. To start community Nutrition Program: Community nutrition is a branch of human nutrition focuses on serving all people, especially in children and to meet their food and nutrition. Also needs to improve or maintain in a healthy state, through all stages of life of the children.

9. Perceptions and knowledge: A concentrated approach to improve awareness among all regarding the importance of nutrition for children is likely to be very useful and breastfeeding practices should be encourage among the lactating mothers. Gender discriminations should be eliminated from the society through awareness rising to ensure intra-household food security.

\section{References}

1. Central Intelligence Agency (CIA), US (2014) The World Fact Book.

2. World Bank (2011) Rice Fortification: A key Part of the Solution to Micronutrient deficiencies. The Agriculture and Rural Development and Health and Nutrition and Population Team, World Bank.

3. World Health Organization (WHO), (2015) Country Profile, Bangladesh.

4. Sclar ED, Northridge ME (2003) Slums, slum dwellers, and health. Am J Public Health 93: 1381. [Crossref]

5. World Urban Forum (2004) Dialogue on the urban poor: improving the lives of slumdwellers.

6. Pryer JA, Rogers S, Normand C, Rahman A (2002) Livelihoods, nutrition and health in Dhaka slums: Public Health Nutrition.

7. Rahman MA (2012): Improvement of Health, Hygiene and Nutritional Status of Urban Slum Dwellers- A Program of RCE Greater Dhaka, Bangladesh.

8. Haque MM, Bhuiyan MR, Naser MA, Arafat Y, Suman KR, et al. (2014): Nutritional Status of Women Dwelling in Urban Slum Area. J Nutr Health Food Eng 1: 00014.

9. Arifeen SE1, Black RE, Caulfield LE, Antelman G, Baqui AH, et al. (2000) Infant growth patterns in the slums of Dhaka in relation to birth weight, intrauterine growth retardation, and prematurity. Am J Clin Nutr 72: 1010-1017. [Crossref]

10. Blössner, M. and de Onis, M. (2005) Malnutrition: quantifying the health impact at national and local levels. Geneva, World Health Organization.

11. UNICEF (2013) IMPROVING CHILD NUTRITION, The achievable imperative for global progress, (C) United Nations Children's Fund (UNICEF) April 2013, United Nations Publications.

12. Faruque AS, Ahmed AM, Ahmed T, Islam MM, Hossain MI, et al. (2008) Nutrition: basis for healthy children and mothers in Bangladesh. J Health Popul Nutr 26: 325339. [Crossref]

13. UNICEF (2011): Child and Maternal Nutrition in Bangladesh.

14. International Centre for Diarrhoeal Disease Research, Bangladesh (Icddr'b), (2012): Baseline survey reveals high under-nutrition amongst children in Bangladesh.

15. Shao AT, Zhou KZ (2007): Marketing research. 240, 3rd edition, London et al. Thomson Learning.

16. Kirkwood BR, Sterne JA (2003): Essential Medical Statistics, Chapter 3 - Displaying the data, page 15, 2nd edition, Black well Publication Ltd.

17. Proctor T (2005): Essentials of Marketing Research, page no. 324, 4th edition, Prentice Hall, UK

18. Bangladesh Bureau of Statistics (BBS), (2015): Multiple Indicator Cluster Survey 2012-2013, Statistics and Informatics Division, Ministry of Planning Government of the People's Republic of Bangladesh Dhaka, Bangladesh CBangladesh Bureau of Statistics (BBS) and United Nations Children's Fund (UNICEF) March, 2015 
19. World Health Organization (WHO), (2005): WHO growth reference standards, Bangladesh

20. bdnews24.com (2015): Bangladesh's per capita income rises to $\$ 1,314$.

21. FAO, (1999): Nutrition Country Profile - BANGLADESH, 25 March 1999, FAO, Rome

22. Leslie J (1991) Women's nutrition: the key to improving family health in developing countries? Health Policy and Planning 61: 1-19
23. World Food Program (WFP), United Nations Children's Fund (UNICEF), Institute of Public Health Nutrition (IPHN) (2009): Household Food Security and Nutrition Assessment in Bangladesh, November 2008-January 2009. WFP/UNICEF/IPHN, Ministry of Health and family Welfare, Bangladesh.

24. Nutrition, health and demographic survey of Bangladesh, (NHDSBD) (2011): Health, Population and Nutrition Sector Development Program, Bangladesh.

Copyright: @2015 Rahman MH. This is an open-access article distributed under the terms of the Creative Commons Attribution License, which permits unrestricted use, distribution, and reproduction in any medium, provided the original author and source are credited. 